\title{
Role of Social Groups and Classes in the Islamic Revolution of Iran
}

\author{
Mohammad Rahimian ${ }^{1} \&$ Abbas Keshavarz Shokri ${ }^{1}$ \\ ${ }^{1}$ School of Humanities, Department of Political Science, Shahed University, Tehran, Iran \\ Correspondence: Abbas Keshavarz Shokri, School of Humanities, Department of Political Science, Shahed \\ University, Tehran, Iran. Tel: 98-215-121-2422. E-mail: keshavarz@shahed.ac.ir
}

Received: May 2, 2017

doi:10.5539/res.v9n3p100
Accepted: May 17, 2017

URL: http://doi.org/10.5539/res.v9n3p100

This article is based on Mohammad Rahimian's M.A. Thesis, Shahed University, Tehran, Iran.

\begin{abstract}
The main objective of the paper is to study the role of social groups and classes and their alliance in the Islamic Revolution. The methodology used in this study is the qualitative document analysis. The results showed that the chasm among social forces was moderately wide before the Revolution and the alliance among social forces was weak after the Revolution and in the new regime, therefore, the extent of transfer of power was so vast which led to a large-scale revolution.
\end{abstract}

Keywords: social class, coalition, revolutionary status, revolutionary consequences, Islamic Revolution

\section{Introduction}

The main objective of the study is to investigate the role of social groups and classes and their alliance in the Islamic Revolution. Max Weber defines the social class based on people's amount and kind of consumption while Karl Marx holds that classes are classified based on whether they own means of production and the class who controls the means of production is the ruling class (Weber, 1976, p. 96).

The class alliance refers to a temporary or permanent unity among social classes and groups. These alliances play a decisive role in the victory of revolutions. In the Islamic Revolution, there was an alliance of social groups and classes such as urban middle class, labor class, farmers, intellectuals and clergymen against the state and more specifically against the Shah himself. All members of the middle class participated in the Revolution including government employees, medium investors, the traditional bazaar (shop) owners and the new industrialists.

The victory of the Iranian nation was an important fundamental development in Iran's society. The Revolution had significant impacts on the society, therefore, it is important to study what actors were active in the Revolution, how the social groups and classes formed an alliance which led to the victory of the Islamic Revolution and finally how various classes came to an agreement and unity against the Pahlavi regime. It needs to be studied how various groups with different and even opposing ideologies formed an alliance together in the Islamic Revolution and made it happen. The main question is what is the contribution of social groups and classes and their alliance to the Islamic Revolution?

\section{Method}

The main question which is addressed in this study is: how various social groups and their coalition contributed to the Iranian Islamic Revolution? To answer this question, documentary method was employed and the necessary data was collected from documents, books and journals of repute.

\section{Results}

Charles Tilly holds that at least a combination of a) revolutionary situation, and b) revolutionary aftermath is required for a revolution to be a genuine revolution. Therefore, the extent of chasm in the revolutionary situation and the extent of the revolutionary aftermath (the former one largely determines the latter) are considered in order to define and explain the typology of each revolution. Large scale revolutions are distinct in rival political societies in terms of revolutionary situation and massive transfer of power and if there is no alliance after the victory of the revolution in the newly-established regime, that may even increase the power transfer. 
In civil wars, middle to high chasm in the revolutionary situation is accompanied with the middle to high extent of power transfer which these revolutionary aftermaths speak of small to big foundations for the revolution to abate. Uprising contains middle to high chasm in the revolutionary situations, but is also a decreasing factor for creating a massive or super massive alliance in the new regime which will slow down the speed of power transfer and it may only happen by a small to medium pace. Coups are defined where there is a small to middle chasm with a small to middle transfer of power which can hasten with a widespread alliance in the revolutionary regime. The low point in the scale of power transfer in large-scale revolutions is similar to the high point in civil wars in terms of magnitude and this, therefore, shows how limited and widespread the new regimes are in comparison to a large-scale revolution or a pure civil war and more importantly various types of revolutions cannot be distinguished from one another.

Consequently, the highest pace of power transfer in uprisings is similar to the lowest pace of civil wars and this also depicts various models of alliance in new regimes (a regime with a more limited base than that of pure uprisings and a more widespread base than that of civil wars) and revolutions of this type can be called uprisings with civil wars. Finally, the highest pace of power transfer in coups is similar to the lowest pace in civil wars, because the existing alliances in the new regimes are more limited than pure coups and the existing alliances in the new regimes are more widespread in civil wars than pure civil wars, therefore, such dualism of revolution are inseparable in this domain. Thus, despite the fact that there are various models of revolutions, they all are succumbed under one category and are not distinguishable in periphery (Taylor, 2009, p. 132).

Table 1. Revolutionary situations, revolutionary aftermaths, types of revolution

\begin{tabular}{cccc}
\hline Type of revolution & Transfer of power & Extent of alliance in the new regimes & Extent of chasm in the revolutionary situations \\
\hline Large-scale revolution & Massive & None, small & Middle to high \\
Civil war/Large-scale revolution & Large & Little & Middle to high \\
Civil war & Middle to high & Relatively widespread & Middle to high \\
Civil war/uprising & Small & Widespread & Middle to high \\
Uprising & Very small & Massively widespread & Middle to high \\
Civil war/coup & Middle to high & None, little & Low to middle \\
Coup & Small & Relatively widespread/widespread & Low to middle
\end{tabular}

Source: Taylor (2009, p. 135).

\subsection{Role of Urban Middle Class on the Islamic Revolution}

Considering their support for Reza Shah during the first Pahlavi period, educated middle class could enjoy education, job and social security. In September 1941, this class, however, expressed their support for Mosadegh and the anti-colonialism in order to achieve democracy. They got drawn aside from the political scene by the 1953 Coup but remained in economic and social spheres due to their technical and academic skills. They continued their opposition through clandestine measures as well as overt protests through channels such as the National Resistance Movement. Educators and academics were the two main groups belonging to this class who were leading the protests against the Pahlavi regime after the Coup. Given the fact that the urban middle class were seeking freedom and technocracy and meritocracy for the management of the country, there was an irreconcilable conflict between them and the regime (Azad Manjiri, 2003, p. 214).

\subsection{Role of the Working Class in the Islamic Revolution}

The main reason that the working class were protesting had to do with the economic recession. During the unrests and protests by the middle class (1977 October-1978 May), there were only seven strikes in the industries, but after 1978 May, the adverse effects of the economic recession began to surface especially in the construction activities, and the state imposed a limit on the salary increases and revoked the annual bonuses which used to paid to all state employees, so the strikes increased dramatically. In mid summer, salary reductions began, workers lost their jobs and the salaries in the construction area decreased by $30 \%$. Such harsh policy towards workers resulted in several strikes. 
In May, the employees of the Tehran Power Plant, southern towns of the Tehran Water Network and a large industrial factory went on strike. Similar reactions happened in Abadan with 600 workers, in Behshar with 1750 workers, in Tabriz with 2000 workers as well as in Fars Paper Factory, Tehran Auto Plant, Ahwaz Auto Plant and Water Plant.

In late September, workers increased their strikes and protests and demanded political and economic privileges. As a result, refineries, petrochemical factories, Kerman Copper Mine and forty big factories were shut down. In late October, due to repeated strikes, all shopping centers, universities, schools, oil plants, banks, ministries, post office, railway stations, newspapers, customs offices, ports, state hospitals, ... and other big factories were closed (Kocharian, 2005, p. 237).

\subsection{Role of Farmers in the Islamic Revolution}

After the land reforms, 200000 absent landowners still owned half of farmlands; in other words, 8 million hectares lands are divided among two million, 4 hectares are allocated to each farmer. On the other hand, these lands vary greatly whether in one village or several. As a result, a new farming class began to become landowners. The members of this class had varying interests according to the size of the lands each member had. These inequalities manifested in 1) an unequal model for landownership, 2) lands were scattered around the country, 3) watering difficulties and finally, 4) self-sustaining agriculture (Koucharian, 2005, p. 55).

In general, due to the land reforms, a new farming class emerged which used to consist $15 \%$ of the farmers' society. This class also used to control rural companies. All in all, the farmers became dependent on the state bureaucracy through such agencies. In the 1978 revolutionary developments, there were several limited cases of support from villagers to the Shah regime, but it disappeared when the protests became nationwide shortly after (Bashirieh, 1995, p. 220).

\subsection{Role of Landowners in the Islamic Revolution}

In 1960s, the state decided to crush the power of landowners. The aristocrats had their power from their lands and the land reforms were considered an end to this power. The $60 \%$ of the eighteenth parliament were consisted of landowning aristocrats. Aristocrats were considered an important influential group. Naturally, their influence would not let the state act against their interests. One major dimension of power struggle was between aristocrats and the imperial court. The defeat of this influential group could be made possible through dominance in the parliament and elections. Consequently, the imperial court began working on creating dependent parties in order to change the social structure of the parliament. The independence of the parliament from the Shah depended on power of the aristocrats (Bashirieh, 1995, p. 204).

Therefore, in 1961, the Shah decided to crush the power of the parliament and aristocracy through the establishment of a powerful reformist cabinet. He censured the Constitution as the guarantor of power for the aristocracy. The shutdown of the parliament for two years and half and the social reforms especially the land reforms put an end to the power of landowning aristocrats. As a result, aristocratic politicians were removed from Iran's political scene. The land reforms were the most important measure against the aristocrats. Due to the land reforms law, landowners could only keep one of their villages and their other lands in other places were divided to others (Bashirieh, 1995, p. 204).

\subsection{Role of the Capitalist Class in the Islamic Revolution}

After the fall of Reza Shah, the state's role in economy diminished, state monopolies became abolished, many foreign aids and loans poured into the country and exports increased, so the trading classes got reinvigorated. Even though during 1940 until 1960, the capitalist classes did not have much political power as the imperial court and army had dominated the political life, their economic power was rising. Private investments increased by $20 \%$ each year. Since 1960 , the growth of these capitalist traders faced serious difficulties after the adoption of the economic reforms policy and emphasis on the domestic production and industries. In opposite, during 1960 until 1979, a new financial and industrial capitalist class emerged (Bashirieh, 1995, p. 153).

Employing syndicates affiliated with the Iran Novin Party established "conference" with ministries about financial issues. At that time, the chamber of trade, industries and mines which was composed of all trading chambers in Tehran and other cities had close cooperation with the Ministry of Economy and Finance on the execution of the state economic policies. Having said that, the state was still skeptical about the increasing growth of this new class in 1970s and termed it as the "industrial feudalism". In 1972, therefore, following the order of the Shah, the Higher Social Council was established in order to stop the insane growth of this new capitalist class and it was decided in the Council that 5000 major private industrial units sell one-third of their shares to workers. Such disagreements between the new capitalist class and the state became a major intrastate 
crisis before the 1979 revolution. Strict control of prices, wage increases, arrest of some big investors, reducing banking credits of the private sector and mobilizing workers created big problems and dissatisfaction within the industrial bourgeoisie (Bashirieh, 1995, p. 158).

\subsection{Role of Intellectuals in the Islamic Revolution}

Intellectuals are those who step beyond the traditional/conventional limits of each area and create new values or reform the old values. They present new intellectual devices in order to interpret various dimensions of life; they use critical thinking to tackle scientific issues, they come up with new philosophies of living and they criticize the political and social status quo. At that time, groups with such features were the Tudeh Party, People's Mujahedin, the National Front, the Freedom Movement and religious intellectuals.

\subsection{Role of Bazaaris in the Islamic Revolution}

All analysts of the Islamic Revolution concur that Bazaar was a key and active part of the religious revolutionaries and played a vital role in overthrowing the Pahlavi regime. Bazaaris joined the revolutionaries in the course of the glorious Islamic Revolution of Iran for a number of reasons and helped the Revolution in several ways. Shutting down their shops was an effective tactic of resistance. Its impact was felt very fast in the economy of the city and could lead to a crisis in many cases. They realized that shutting down their shops in a coordinated way was a provocative action which conveyed a message to the regime and people. Bazaaris also had a significant role in providing financial means for the Revolution and were the most fervent supporters of Imam Khomeini (Foran, 1993, pp. 554-568).

On the anniversary of the Khordad 15th uprising (5 June, 1978), the first coordinated closing of shops occurred. In 1975, the Municipality of Tehran admitted that there was a proposal of constructing a main road which would pass right through the Bazaar. In 1977, the fight against the so-called overcharging led to more dissatisfaction. Therefore, Bazaaris made considerable financial donations to holding demonstrations, strikes, riots and publication of revolutionary declarations and dissemination of banned tapes, books as well as financial aids to those imprisoned religious scholars, revolutionary forces and their families who had faced difficult situations (Ashraf, 2009, pp. 149-151).

\subsection{Role of Clergymen in the Islamic Revolution}

Clergymen have always had an active role in all the revolutions that have taken place in Iran. In his book entitled "Political Sociology", Bashirieh explains about the attitude of clergymen towards their involvement in governing:

(1) The more social and politics motives of religion, the more clergymen interfere in the political sphere. (2) when clergymen, as a political force, have a better reputation historically, they will be more likely to interfere directly and massively in politics. And finally (3) when the religion is subject to interpretation and is flexible and compatible with various historical developments, clergymen will be more able to interfere directly in politics.

As far as the Islamic Revolution is concerned, there were three groups of clergymen. The first group were supporters of the engagement of clergymen with politics. The second group were supportive of the Pahlavi regime and the third group were clergymen who were strongly opposed to any interference by clergymen or religious scholars. The first group demanded that clergymen engage in politics. Their slogan was "our politics is exactly like our religion and our religion is exactly like our politics". Notable figures in this group included Imam Khomeini, Motahari, Ayatollah Taleghani, Ayatollah Beheshti and Ayatollah Montazeri among others. They held that Shia'a (religion) would never allow a corrupt and authoritarian person to rule over the country, they were strongly against the Pahlavi regime. In the second group, the most notable person was Ayatollah Shariatmadari and in the third group figures like Ayatollah Khoei and Ayatollah Borujerdi can be found.

\subsection{Alliance of Social Classes in the Islamic Revolution}

There were three main groups who developed the ideological principles and financial means of the Revolution: the young intellectuals, the fighting clergymen and the younger Bazaaris. Government employees and industrial workers joined them in the latest stages of the Revolution and made the social base of the Revolution bigger. Therefore, they were able to coordinate strikes which brought the economy to the edge of bankruptcy and ultimately paralyzed the official bureaucracy. The urban impoverished people and rural immigrants took part in popular demonstrations which sometimes turned to violence as the police and army tried to crush them. But they never took the lead and merely acted like extras.

Students, discontent intellectuals, writers, human rights activists and lawyers were among the first who blatantly defied the Pahlavi regime. In the early months of 1978, they used the flexibility of the regime on the political 
disobedience to hold some peaceful activism including writing open letters, peaceful demonstrations, poetry reading nights and public gatherings. These activities were not subject to state censorship since it would be condemned as the infringement of citizens' political and civil rights. In the last two years before the Revolution, the young intellectuals participated in all forms of protests. The young intellectuals along with the young Bazaaris contributed closely to the half of 1200 strikes which had taken place in September and October of 1978. Imam Khomeini urged clergymen to have a more active role: "writers of various political parties are writing letters and denounce the (Pahlavi) regime, you also need to write letters and get them signed by a hundred religious scholars".

The third main factor in the revolutionary alliance was the Bazaar which was composed of traders, shopkeepers, craftsmen and their novices. Many efficient tactics for mobilizing people were conducted by the young Bazaaris under the leadership of some religious scholars. Also, the Bazaaris were financially supportive of other revolutionary groups.

The new middle class also joined the Revolution in the later stages and when there was no harsh reaction from the regime, like students and Bazaaris, they organized more serious demonstrations and strikes. Having said that, most of their contributions were intended express their demands for higher wages and were confined to peaceful strikes or other similar activities. They also participated in street demonstrations organized by other groups.

The industrial working class also joined the Revolution like other government employees. These workers often went on strike as their higher colleagues did. Their strikes were so effective that could basically shut down many industries and services.

In the final stages of the Revolution (1978, October until 1979, February), a small limited protest by the young intellectuals turned into massive nationwide demonstrations which attracted almost all social classes. The notable clergymen had an increasingly determining role in the movement and they promised an utopian Islamic state under the leadership of a charismatic and uncompromising figure like Imam Khomeini. Discontent with the regime and looking forward to a better future, all social groups remained united until the victory of the Revolution on 11, February 1979. The victory of the Revolution occurred sooner than expected. It was not only a sign of a great leadership which attracted almost all social groups and classes but also showed that the Pahlavi regime failed to keep loyal the social classes it helped create. There is much irony in the fact that these social groups and classes did enjoy the benefits directly from the social and economic policies of the regime.

\section{References}

Ashraf, A., \& Banu Azizi, A. (2009). Social Classes, State and the Revolution in Iran (S. T. Farsani, Trans.). Niloofar Publications, Tehran.

Azad Manjiri, M. (2003). Comparison of the Islamic Revolution of Iran with the French Revolution (in Farsi language, Master Thesis). Department of History, Islamic Azad University, Tehran, Iran.

Bashirieh, H. (1995). Political Sociology. Role of Social Forces in the Political Life (17th ed.). Ney Publications, Tehran. (in Farsi language).

Foran, J. (1993). Fragile Resistance: Social Transformation in Iran from 1500 to the Revolution (A. Tadayon, Trans.). Westivew Press.

Kakavand, Y. (2010). Role of Alliance of Clergymen, Intellectuals, Bazaaris in the formation of Iran's Contemporary Movements from the Constitutional Revolution to the Islamic Revolution (in Farsi language, Master Thesis). Shahed University of Tehran, Tehran, Iran.

Koucharian, N. (2006). Comparison of Social Classes Pre- and Post-Revolution (in Farsi language, Master Thesis). School of Social Science and Psychology, Islamic Azad University, Tehran Central Branch, Tehran, Iran.

Mir Sepasi, A. (1992). Crisis of Secular Politics and Emergence of Iran's Political Islam (M. Khaleghi, Trans.). Pajoohesh Quarterly, 10-11.

Najafi, M. (1998). Introduction to the Analysis of History of Iran's Political Developments: Religion, State and Modernism (in Farsi language). Monir Publication and Cultural Institute, Tehran, Iran.

Nejati, G. (1992). Iran's Twenty-Five-Year-Old History: From the Coup to the Revolution (in Farsi language, 3rd ed., Vol. 2). Rasa Publications, Tehran, Iran.

Taylor, S. (2009). Social Sciences and Revolutions (A. Morshedizad, Trans.). Shahed University Publications, Tehran. 
Weber, M. (1976). Basic Concepts in Sociology (A. Sedarati, Trans.). Markaz Publication, Tehran, Iran.

\section{Copyrights}

Copyright for this article is retained by the author(s), with first publication rights granted to the journal.

This is an open-access article distributed under the terms and conditions of the Creative Commons Attribution license (http://creativecommons.org/licenses/by/4.0/). 